An Affirmative Action/Equal Opportunity Employer

This report was prepared as an account of work sponsored by an agency of the

United States Government. Neither the United States Government nor any agency thereof, nor any of their employees, makes any warranty, express or implied, or assumes any legal liability or responsibility for the accuracy, completeness, or usefulness of any information, apparatus, product, or process disclosed, or represents that its use would not infringe privately owned rights. Reference herein to any specific commercial product, process, or service by trade name, trademark, manufacturer, or otherwise, does not necessarily constitute or imply its endorsement, recommendation, or favoring by the United States Government or any agency thereof. The views and opinions of authors expressed herein do not necessarily state or reflect those of the United States Government or any agency thereof. 
UC-700 and UC-705

Issued: March 1991

$L A--11890$

DE91 007888

\section{Preparation of Pure Neptunium Oxide}

for Nondestructive Assay Standards

S. L. Yarbro

S. L. Dunn

S. B. Schreiber 


\title{
PREPARATION OF PURE NEPTUNIUM OXIDE FOR NONDESTRUCTIVE ASSAY STANDARDS
}

by

S. L. Yarbro, S. L. Dunn, and S. B. Schreiber

\begin{abstract}
Accurate nondestructive assay (NDA) measurements, particularly with gamma spectrometry, require pure material standards. The purity of materials used as standards is verified bu reliable chemical techniques, and these materials are then used to calibrate and certify NDA instruments. So that they can be used for this purpose, impure $\mathrm{NpO}_{2}$ and metal were each purified by a different procedure. The $\mathrm{NpO}_{2}$, which contained more than $2500 \mathrm{ppm}$ plutonium, was purified by a double peroxide precipitation, followed by ion exchange and oxalate precipitation of the eluate. All impurities, includirg plutonium, were below $100 \mathrm{ppm}$ in the product. The metal, which contained more than $10000 \mathrm{ppm}$ of tantalum, was dissolved in 12 $\mathrm{M} \mathrm{HCl}$ and then precipitated as the $\mathrm{Np}(\mathrm{IV})$ oxalate. The final product was below 100 ppm of all impurities except calcium.
\end{abstract}

\section{INTRODUCTION}

A variety of actinide isotopes are processed at the Plutonium Facility at Los Alamos. These isotopes are used to support many ongoing activities in weapons research design and testing, studies involving the SP100 space reactor, research into milliwatt heat sources, and other program areas. Processing these actinide materials produces waste items that must be assayed before going on to further processing or disposal. Many of these items are complex matrices, such as broken glass or plastics, for which nondestructive assay (NDA) methods provide the best and most reliable analysis. At Los Alamos, the vigorous program to develop robust NDA techniques often requires pure materials for calibrating and certifying instruments. Of the $570 \mathrm{~g}$ of pure $\mathrm{NpO}_{2}$ provided for gamma assay standards, $500 \mathrm{~g}$ of oxide was sent to New Brunswick Laboratory so that standards could be manufactured for the DOE complex and others as required, and $70 \mathrm{~g}$ remained at Los Alamos to be used as part of a program to develop an accurate gamma spectrometry technique for neptunium.

\section{EXPERIMENTAL EQUIPMENT AND MATERIAL}

The feedstock for preparing the pure $\mathrm{NpO}_{2}$ was impure neptunium uxide and metal. The assays for each appear in Table I. 


\begin{tabular}{ccc}
\hline \hline Table I. & Trace Metals Analysis of Neptunium Feedstock \\
\hline Trace Metal & $\mathrm{NpO}_{2}(\mathrm{ppm})$ & Np Metal (ppm) \\
\hline Aluminum & 8300 & - \\
Beryllium & 30 & - \\
Calcium & 4000 & $>1000$ \\
Chromium & 25 & - \\
Copper & 25 & - \\
Iron & 240 & - \\
Magnesium & 16000 & - \\
Manganese & 10 & - \\
Sodium & 500 & - \\
Nichal & 40 & - \\
Lead & 16500 & - \\
Silicon & 110 & - \\
Tin & 35 & - \\
Tantalum & $<5$ & $>10000$ \\
Plutonium & 2600 & $<100$ \\
Americium & 6 & $<100$ \\
\hline \hline
\end{tabular}

All the chemicals, such as nitric and hydrochloric acid, hydroxylamine hydrochloride, and ascorbic acid, were reagent-grade materials from either J. T. Baker or Eastman Kodak. The equipment was standard laboratory glassware, such as 600 -ml, medium-glass-filter frits and beakers. One-half-inch lead shielding wrapped vith plastic tape reduced exposure to the high gamma radiation produced by the ${ }^{233} \mathrm{~Pa}$ daughter product from ${ }^{237} \mathrm{~Np}$ decay. The neptunium was more than $99 \%$ of the 237 isotope.

\section{PROCEDURE FOR $\mathrm{NpO}_{2}$}

Because the aqueous chemistries of neptunium and plutonium are similar in many respects, we decided to use proven plutonium purification techniques to purify the $\mathrm{NpO}_{2}$.

The particular flow sheet followed in the iurification process was chosen because of the variety of contaminants in the starting oxide. The peroxide precipitation removed the cations, such as iron, that would not be removed in the chloride ion-exchange step. The chloride was used primarily to separate neptunium and plutonium. The plutonium was reduced to the nonextractable (III) state and the neptunium to the (IV) state. For the metal, plutonium was not present, so only an oxalate precipitation was used to convert the metal to a reasonably pure oxide.

\section{A. Dissolution with Nitric Acid}

Because the starting $\mathrm{NpO}_{2}$ material was "foundry oxide" and had been derived from burning neptunium metal, we assumed that the oxide would be refractory and difficult to dissolve. Therefore, the following procedure was used: total acid volume was calculated by adding $5 \mathrm{ml}$ of $15.6 \mathrm{M} \mathrm{HNO}_{3}$ per gram of $\mathrm{NpO}_{2}$. After calculating the acid volume, we determined the amount of $28 \mathrm{M} \mathrm{HF}$ to bring the total free fluoride content to $0.05 \mathrm{M}$. The HF was added in two equal-volume increments: one at the beginning of the dissolution and the second after $2 \mathrm{~h}$ at reflux. After the material had been at reflux for $4 \mathrm{~h}$, the heat was increased to distill the mixture, reduce the volume, and increase the neptunium concentration to between 250 and $300 \mathrm{~g} /$. After distillation, the mixture was cooled and then filtered through a $600-\mathrm{ml}$ medium-glass-filter frit. 
The dissolution proceeded very well; essentially $100 \%$ of the material dissolved. This behavior is different from that of $\mathrm{PuO}_{2}$ in that refractory $\mathrm{PuO}_{2}$ is much more "ceramic" in naiure and much more difficult to dissolve. Neptunium seems to behave more like uranium oxides and the high-fired material is more soluble.

\section{B. Double Peroxide Precipitation}

To prepare for the peroxide precipitation, we used the procedure developed by G. A. Burney and E. K. Dukes ${ }^{1}$ as a guideline. The neptunium nitrate solution was titrated at $10.4 \mathrm{M}$ after filtration. We adjusted the acid to $5.0 \mathrm{M}$ by diluting with $0.5 \mathrm{M} \mathrm{HNO}_{3}$. No sulfate was added for the first precipitation. The solution was cooled to below $21^{\circ} \mathrm{C}$ and $10 \mathrm{M} \mathrm{H}_{2} \mathrm{O}_{2}$ was added slowly. The peroxide addition was complete when a 20:1 mole ratio of peroxide to neptunium was achieved. As the precipitation proceeded, the color changed from light green to gray to light purple. The addition rate of peroxide averaged 8 to 10 $\mathrm{ml} / \mathrm{min}$. After all the peroxide was added, the cooling water was turned off and the solution was allowed to digest for $30 \mathrm{~min}$

The material was then filtered through a $600-\mathrm{ml}$ medium-glass-filter frit. The filtrate was light yellow, and the precipitate filtered reasonably well with no solids going through the filter. The precipitate was purple and was washed with four bed-volumes of $0.5 \mathrm{M} \mathrm{HNO}_{3} / 5 \% \mathrm{H}_{2} \mathrm{O}_{2}$. After the precipitate had been dried with vacuum in the frit, the material was dissolved in $12 \mathrm{M} \mathrm{HCl}$. We calculated the volume of $\mathrm{HCl}$ required by using enough acid to have an ending acid concentration of 4 to $5 \mathrm{M}$ after complete dissolution of the cake. The peroxide cake was reactive and was dissolved by slowly adding it to the acid. The dissolution proceeded smoothly, requiring no heating or filtration.

At this point, the solution was titrated and brought up to $0.05 \mathrm{M}$ in sulfate with sulfuric acid. In plutonium peroxide precipitations the sulfate improves the filtering characteristics of the cake. The solution was cooled to below $21^{\circ} \mathrm{C}$ and $10 \mathrm{M} \mathrm{H}_{2} \mathrm{O}_{2}$ was added at 8 to $10 \mathrm{ml} / \mathrm{min}$ until a $20: 1$ mole ratio was achieved. Again, the solution was allowed to warm and digest for $30 \mathrm{~min}$. The solution was filtered through a $600-\mathrm{ml}$ medium-glass-filter frit. The solution was clear, and the material filtered reasonably well.

\section{Chloride Anion Exchange}

1. Feed Pretreatment. After the cake from the second peroxide was dissolved, the acid concentration was adjusted to $10 \mathrm{M}$ in $\mathrm{HCl}$. Then, a 1:1 mole ratio of ascorbic acid to neptunium was added to reduce the valences and allowed to digest for $30 \mathrm{~min}$. A large excess was used because prior ion-exchange trials revealed that plutonium was oxidized back to the (IV) state and would follow the neptunium and not be separated.

2. Resin Pretreatment. Reillex HPQ, macroporous, strong-base anion resin-a polyvinylpyridinebased material-was selected for the neptunium ion-exchange step. The resin was obtained in the chloride form and was washed with two bed-volumes of $10 \mathrm{M} \mathrm{HCl}$ and $0.1 \mathrm{M}$ hydroquinone in preparation for the ion-exchange step.

3. Batch Anion Exchange. We minimized waste volumes by using a batch equilibration step instead of a flow column. We calculated the quantity of resin needed by estimating the amount of resin required for a similiar amount of plutonium and doubling that amount. The resin was gently mixed with the neptunium feed in a 4-1 beaker for $30 \mathrm{~min}$. Occasionally, the stirring was stopped, and the resin was allowed to settle. We visually checked the color of the solution to verify the completeness of the reaction. The resin was separated by filtration and then washed in the medium-glass-filter frit with 1.5 bed-volumes of $10 \mathrm{M} \mathrm{HCl}$ and $0.1 \mathrm{M}$ ascorbic acid. The neptunium was then eluted with 1.5 bed-volumes of $0.5 \mathrm{M} \mathrm{HCl}$. 


\section{D. $\mathbf{N p ( I V )}$ Oxalate Precipitation}

The $\mathrm{HCl}$ concentration of the eluate was adjusted to 3 to $4 \mathrm{M}$. A 1:1 mole ratio of hydroxylamine hydrochloride to neptunium was added to hold the neptunium in the (IV) state. The mixture was allowed to digest for $15 \mathrm{~min}$ and then slowly heated to between $50^{\circ} \mathrm{C}$ and $60^{\circ} \mathrm{C}$. We then added $1 \mathrm{M}$ oxalic acid at 7 to $10 \mathrm{ml} / \mathrm{min}$ until $0.1 \mathrm{M}$ excess oxalic acid was present. The lime-green precipitate was filtered through a $600-\mathrm{ml}$ medium-glass-filter frit. The material filtered well with a clear, light-green filtrate.

\section{E. Calcination}

The oxalate cake was dried overnight with vacuum on the frit. It was then calcined in a muffle furnace at $200^{\circ} \mathrm{C}$ for $2 \mathrm{~h}, 400^{\circ} \mathrm{C}$ for $2 \mathrm{~h}, 600^{\circ} \mathrm{C}$ for $2 \mathrm{~h}$, and $950^{\circ} \mathrm{C}$ for $2 \mathrm{~h}$. The final oxide product was a fine, dark-green powder.

\section{PROCEDURE FOR NP METAL}

\section{A. Metal Dissolution with $\mathrm{HCl}$}

The impure metal, slightly encrusted with $\mathrm{NaCl}$ and $\mathrm{KCl}$ salts from the electrorefining process, was placed in a 4-l beaker. We added $12 \mathrm{M} \mathrm{HCl}$ very slowly because the metal dissolves rapidly in $\mathrm{HCl}$ and because the reaction is very exothermic and evolves hydrogen. The acid volume was calculated to dissolve all of the metal and end with an acid concentration of 3 to $4 \mathrm{M}$. After adding the acid, we stirred the reaction mixture for $30 \mathrm{~min}$ and then filtered it through a $600-\mathrm{ml}$ medium-glass-filter frit.

\section{B. Precipitation}

The solution was precipitated and calcined according to the procedure outlined above in sections III D and $\mathrm{E}$.

\section{RESULTS AND DISCUSSION}

The analytical results for the different product oxides appear in Table II.

Both methods were reasonably successful and provided a pure $\mathrm{NpO}_{2}$ standard. In the first method, essentially $100 \%$ of the oxide and peroxide dissolved in every case. This uniformity helped make accurate calculations of acid and neptunium concentrations for reagent make-up. The peroxide precipitations removed all trace metals except plutonium. The peroxide filtrate averaged about $400 \mathrm{mg}$ of neptunium per liter. Lowering the initial acidity would decrease the solubility ${ }^{1}$; however, doing so would have increased the volume and been more difficult to handle. In all cases, the peroxide cake was more gelatinous than was the oxalate, and the peroxide process was more sensitive to process parameters than was the oxalate.

The ion-exchange resin showed a large decrease in capacity for neptunium as compared with plutonium. Effluents averaged $6 \mathrm{~g}$ of neptunium per liter, a value that is much too high. Spectrophotometric data showed that essentially all of the neptunium in the effluent was in the (IV) state, and acid titrations confirmed the proper acid concentration. Therefore, we can offer no explanation for this behavior. How'ever, the ion-exchange step did provide a complete separation of the plutonium and neptunium.

Oxalate precipitation steps in both methods were very insensitive to process conditions. Even the addition of solid oxalic acid caused a nice, crystalline precipitate to form. In all cases, filtration was rapid and the filtrate averaged $190 \mathrm{mg}$ of neptunium per liter.

The oxalate cake decomposed easily and provided a dark-green. fine powder. A small sample of the $\mathrm{NpO}_{2}$ calcined at $950^{\circ} \mathrm{C}$ was allowed to stand in the glovebox environment over a period of a month and was weighed every three days. It showed no appreciable weight gain over that time. Therefore, the high-fired $\mathrm{NpO}_{2}$ was reasonably inert and did not appear to absorb gases on the surface. 


\begin{tabular}{ccc}
\hline \hline Table II. & \multicolumn{2}{c}{ Analytical Results for Product Oxides } \\
\hline Trace Metals & Method 1 (ppm) & Method $2(\mathrm{ppm})$ \\
\hline Aluminum & 30 & 55 \\
Beryllium & 10 & $<1$ \\
Calcium & $<3$ & 1200 \\
Chromium & 10 & - \\
Copper & $<1$ & $<1$ \\
Iron & 35 & $<5$ \\
Magnesium & $<1$ & $<1$ \\
Manganese & $<1$ & $<1$ \\
Sodium & 50 & 10 \\
Nickel & 15 & 7 \\
Lead & $<5$ & $<5$ \\
Silicon & 80 & 5 \\
Tin & $<5$ & $<5$ \\
Tantalum & $<1$ & 500 \\
Plutonium & 90 & 20 \\
Americium & 0.1 & 10 \\
\hline \hline
\end{tabular}

\section{SUMMARY}

Two methods for purifying $\mathrm{NpO}_{2}$ have been developed: the first method is used for $\mathrm{NpO}_{2}$ that has plutonium as an impurity, and the second method is used for oxide that has only nonplutonium metals as impurities. Both methods produced high-quality oxide for standards and can be applied on a 50- to $500-\mathrm{g}$ scale. Personnel exposures should be minimized by careful shielding and using proper procedures. Even with shielding, exposures to the hands and arms can be high because of the handling requirements.

\section{ACKNOWLEDGMENT}

We acknowledge the contribution of Darryl Jackson of the Analytical Chemistry Group for providing analytical and project support.

\section{REFERENCES}

1. G. A. Burney and E. K. Dukes, "Precipitation of Neptunium Oxalate," DP-594, E. I. DuPont de Nemours \& Co., Savannah River Laboratory, July 1961. 

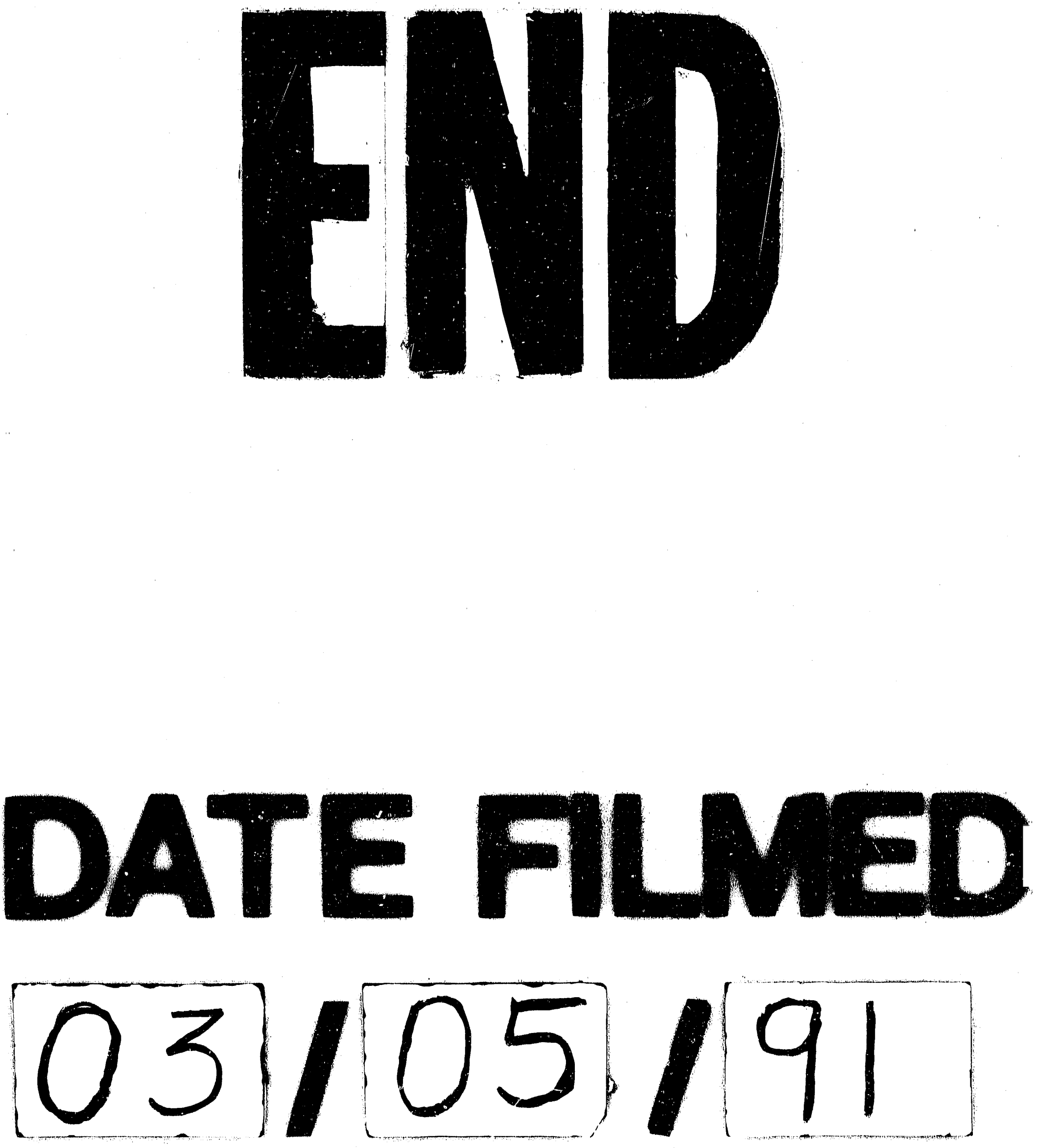
, in 